\title{
Kai Padberg
}

\section{New Forms of Communities? The Constitution and Performance of Audiences in Digital Theater during the COVID-19 Pandemic}

The critical question for many theaters in the year 2020 centered around the possibility of staying in touch with their audiences. The question arose not only due to economic concerns and the political considerations of publicly funded theaters, but because the audience is necessary for the existence of theater as an art form in itself. A crisis of assembly emerged through the pandemic, and, above all for the theaters, a crisis of audience and of co-presence. This was summarized by the philosopher Armen Avanessian at an online-conference on post-pandemic

This article presents research funded by the Deutsche Forschungsgemeinschaft (DFG, German Research Foundation) under Germany's Excellence Strategy in the context of the Cluster of Excellence "Temporal Communities: Doing Literature in a Global Perspective"-Exc 2020-Project ID 390608380. 
theater in November 2020.' The COVID-19 pandemic, which turns an assembly of bodies in one space into a danger for all involved, forced many theater makers to rethink their audiences.

A commonly used option for theaters as cultural institutions, as well as for the design of artistic work-although not the only option and not without controversy-was to intensify or re-establish contact with the audience on the internet. Due to the enforced spatial distance, the social dimension of theater, which connects with the idea of audiences being "communities of reception or of performance," was at stake. The CoviD-19 pandemic has given impetus to artistic forms worldwide which embraced digital spaces. In the theater scene in Germany, many things have been attempted online. Examples include: live-streamed performances, the opening up of theater archives and online access to recordings of historical performances, activities on social networks like Facebook, or experiments with virtual reality chatrooms. A lot has been done to create a theater that is compliant with pandemic regulations, and, in this process, performing artists set out to find new forms of performing art. This search reveals ongoing hybridization, where new forms of theatrical and performative live events are constituted on the internet. Often these include productions where the boundaries between movie, television, computer game, theater, and performance art become increasingly blurred.

The concept of the theatrical event, familiar cultural markers of theater institutions, and the accompanying definitions and expectations of audiences-in other words, many elements of what the theater scholar Susan Bennett in her theory of production and reception called the "outer frame" 3 - have been questioned in the processes. In theater, the assembly of bodies in immediate proximity has always offered a renegotiation of the rules of social interaction. ${ }^{4}$ But what does it mean for the character of an assembly and the rules of social interaction when, for example, instead of bodies in a theater, avatars or filmed bodies now gather via video conferencing software? For theater, these new assembly practices interrogate "how new medial possibilities of communication also require other forms of encounter and community organization, or what is the state of the collective in the age of networks." 5 Digital theater audiences differ significantly in their constitution, their repertoire of actions and reception attitude from the long-practiced

\footnotetext{
${ }^{1}$ Literaturforums im Brecht-Haus, Postpandemisches Theater: Die Krise Der Versammlung (2020), YouTube video, accessed May 29, 2021, https://www.youtube.com/watch?v=wYogkosıu6l, 00:10:20.

2 Jens Roselt, "Gemeinschaft/Kollektivität," in Metzler Lexikon Theatertheorie, eds. Erika Fischer-Lichte, Doris Kolesch, and Matthias Warstat (Stuttgart: Verlag J.B. Metzler, 2014),128.

3 Susan Bennett, Theatre Audiences: A Theory of Production and Reception (London: Routledge, 1994), 3.

4 See Kirsty Sedgman, The Reasonable Audience: Theatre Etiquette, Behaviour Policing, and the Live Performance Experience (Cham: Springer International Publishing, 2018), 6, https://doi.org/10.1007/978-3-319-99166-5.

5 Roselt, “Gemeinschaft/Kollektivität," 131.
} 
conventions or social roles which shaped the image of the "reasonable audience"6 still dominant in Western theater institutions.

With the rise of online theater facilitated by the pandemic, the question of what it actually means to be a theater audience requires a series of new answers. In this article I want to present and discuss two hybrid digital theater productions from Germany, showing how the possibilities of reception and forms of communitybuilding change depending on the platform and the program. The focus will be on productions which address the social dimensions of the audience by turning the viewers into a temporal community.

\section{Theater, Audience, and Modes of Reception in Digital Times}

To begin, I will outline some terminology and theoretical frameworks. Prepandemic audience experience research on live digital streaming of theater performances to individual viewers emphasizes the importance of "liveness" in the perceptions of many audience members. For example, Erin Sullivan writes that $77.1 \%$ of the surveyed viewers of a live stream of $A$ Midsummer Night's Dream from London's Globe Theatre in 2016 were excited by the fact that the stream was live. ${ }^{7}$ Sullivan concludes:

For these spectators, the opportunity to watch the performance in real-time appears to have instilled their experience with a sense of specialness and enhanced participation. They were not just viewing a recording that could be watched at any time; rather, they were taking part in a unique, communal, and time-limited event. ${ }^{8}$

Following up on Sullivan's observation, when it comes to investigating forms of communality in digital theater, it seems to make sense to stick to the idea of the theatrical event as unique, communal, and time-limited. Even if the "witnessing of the real body and the real space" 9 is questioned in digital performances, other central elements of Erika Fischer-Lichte's concept of performance should be retained in reflecting upon the audiences of digital theater. The specifics of the mediality of performances, such as the shared time and mutual production of the performance through actors and spectators, as well as the reciprocal effect in the form of the autopoietic feedback loop, can make theater a theatrical event, even

\footnotetext{
6 Sedgman, The Reasonable Audience.

7 See Erin Sullivan, "Live to Your Living Room: Streamed Theatre, Audience Experience, and the Globe's A Midsummer Night's Dream," Participations: Journal of Audience \& Receptions Studies 17, no. 1 (2020): 99.

8 Sullivan, "Live to Your Living Room," 99.

9 Max Hermann, "Das theatralische Raumerlebnis," in Zeitschrift für Ästhetik und allgemeine Kunstwissenschaft: 4. Kongress-Bericht 25(1931): 152.
} 
in digital forms. ${ }^{10}$ Although the character of feedback loops or the experience of liveness change significantly, and the hybridization of forms generates borderline cases, it is worthwhile to hold on to these elements as concepts of performance. This also allows us to differentiate digital performances from streaming, which function as video-on-demand, and to narrow down the search for theatrical events in the digital space.

Audience in the sense of theater studies is - just like the performance-a fleeting, transitory phenomenon. The audience is initially only characterized by the existence of a group of spectators in a performance. The performance is simultaneously co-produced by the audience." During the performance, the audience is constituted by the fact that they are addressed and have a common focus; ${ }^{12}$ this group is formed into an audience and can form a community of reception. ${ }^{13}$ It is precisely this contingency that exists during the performance that it makes difficult to determine further fixed characteristics of the concept of the audience. Though audiences are often statistically recorded, and their socio-economic data are analyzed within the framework of audience development in theaters and in empirical audience research, ${ }^{14}$ this data does not usually reveal much about the aesthetic experience or practices of the group in the context of the performance. Often, watching and listening are described as key characterizing activities of audiences. However, other collective practices such as applause ${ }^{15}$ or shared silence or laughter are also associated with the historically changing practices and conventions of theater audiences. ${ }^{16}$ Within the context of contemporary Western mainstream theater, theater scholar Caroline Heim proposes to understand the audience as a social role in which audience members stage themselves and which they perform in performances. ${ }^{7}$

A basic difficulty that audience research has repeatedly faced, both conceptually and methodologically, concerns the relationship between the individual and the group in the concept of audience. Helen Freshwater problematizes this as follows:

10 See Erika Fischer-Lichte, "Aufführung," in Fischer-Lichte et al., Metzler Lexikon Theatertheorie, 17-21.

1 See Wilmar Sauter, "Publikum," in Fischer-Lichte et al., 273.

12 See Doris Kolesch and Hubert Knoblauch, "Audience Emotions," in Affective Societies: Key Concepts, eds. Jan Slaby and Christian von Scheve (London: Routledge, 2019), 253.

13 See Roselt, "Gemeinschaft/Kollektivität," 129.

14 Cf. Patrick Glogner-Pilz and Patrick S. Föhl, eds., Handbuch Kulturpublikum: Forschungsfragen und -befunde (Wiesbaden: Springer vs, 2016)

15 See Bettina Brandl-Risi, "Genuss Und Kritik: Partizipieren Im Theaterpublikum," in Vom Publicum: Das Öffentliche in Der Kunst, ed. Dietmar Kammerer (Bielefeld: transcript Verlag, 2014)

16 See Roselt, "Gemeinschaft/Kollektivität," 130.

17 See Caroline Heim, Audience as Performer: The Changing Role of Theatre Audiences in the Twenty-First Century (New York: Routledge, 2015), 4. 
The common tendency to refer to an audience as 'it' as a single entity, or a collective, risks obscuring the multiple contingencies of subjective response, context, and environment which condition an individual's interpretation of a particular performance event. ... So, it is important to remember that each audience is made up of individuals who bring their own cultural reference points, political beliefs, sexual preferences, personal histories, and immediate preoccupations to their interpretation of a production. ${ }^{18}$

Freshwater reminds us that the term "audience" describes a communal situation in which individuals find themselves. At the same time, individuals as an audience can make experiences as a group, beyond the experiences of the individual. ${ }^{19}$ In reference to anthropological ritual theory and the associated ideas of "liminality and communitas," 20 theater scholars have pointed out that audience in a performance can experience itself as a community. Through the collective experience and the ritualistic structure of theater, the possibility arises for audience members to encounter each other as a community of equals with a special connectedness that goes beyond being in the same situation. ${ }^{21}$ These experiences are also politically ambivalent. ${ }^{\mathbf{2 2}}$

The tense and complicated relationship between the individual and the group in an audience becomes even more so in digital performances. Here, the communal situation is no longer given per se. While in many analogue forms of theater the audience assembles in one place, in a bodily-present way, and theater as a practice of encounter between performers and audience has a formative constant, such acts of assembly are not automatically apparent in digital formats. Also, the physical and perceptual relationship to theater buildings as cultural institutions, which are important for the cultural framing and the experience of a performance, falls away. ${ }^{\mathbf{2 3}}$ Bodies - especially during a global pandemic — are not in a shared physical space where they can perceive one another. Thus, in order to go beyond the perception of the individual, the audience as an addressed group experiencing a theatrical event together must once again be separately generated and constituted in digital performances. During the pandemic, theater makers were often faced with the

18 Helen Freshwater, Theatre \& Audience (London: Palgrave Macmillan, 2009), 5-6.

19 See Roselt, “Gemeinschaft/Kollektivität," 130.

20 Victor Turner, "Liminalität und Communitas," in Ritualtheorien: Ein einführendes Handbuch, eds. Andréa Belliger and David J. Krieger (Wiesbaden: vs Verlag für Sozialwissenschaften, 1998), 251.

${ }^{21}$ See Matthias Warstat, "Liminalität," in Fischer-Lichte et al., Metzler Lexikon Theatertheorie, 197-198.

22 See Roselt, "Gemeinschaft/Kollektivität,"130.The German term Gemeinschaft and the related concepts of community have been criticized, especially in German-language theater discourse. This criticism results from the examination of theatrical cultural events, such as the Thingspiele during German fascism. Here, community was understood as Volksgemeinschaft, which created community primarily through racist and antisemitic degradation and exclusion.

${ }^{23}$ See Bennett, Theatre Audiences, 136-137. 
question and challenge of whether they wanted to, and could, make it possible for their audience to experience the theatrical event as a group, and if so, how.

Therefore, theater makers had to deal with the peculiarities of digital spaces and their forms of communication. Web 2.0, in particular, has become known for digital interactions and communication between people in social networks based on media technology. In the spaces of the public sphere of Web 2.o, users are not only recipients, but can also produce their own content, as evident in the term "prosumer." ${ }^{24}$ While Bree Hadley in Theatre, Social Media, and Meaning Making describes social media primarily as a site of debate about theatrical encounters, ${ }^{25}$ Patrick Lonergan in Theatre and Social Media sees these media as a performance space where, in the context of theaters, performances are extended and prolonged through digital re-performances of particular elements by audience members. ${ }^{26}$ Hadley also points to the importance of social media's influence on theater culture: "The uptake of social media is changing the way theater makers inform, educate, entertain or proselytise onstage. It is changing the way spectators perceive and interpret what they see onstage." ${ }^{27}$ I would go a step further and say that, especially after accelerated developments in digital theater during the pandemic, social media can now also present their own places of theatrical encounter. This not only extends performance, but also enables independent theatrical encounters.

The consequences of some of these changes for theaters could even be observed before the COVID-19 pandemic, as evidenced for example in Sullivan's study cited at the beginning of this article. In the case of audiences who watch live-streams of theatrical performances from home, the ideal of the concentrated, absorbed spectator is changing; theater is now confronted with an increasingly diffuse and dispersed audience characterized by multimedia and multitasking. ${ }^{28}$ Disciplining forms of audience behavior policing that brought the notion of the "unspoken theater contract" 29 lose much of their influence when audience members participate from their own private spaces. In rare cases the old ideals of reception are already strongly internalized and also work digitally. This can be exemplified by an interview with the blogger and theater critic Konrad Kögler from Germany's best-known online platform for theater criticism, nachtkritik.de. When asked about the importance of being in the presence of other audiences and whether he uses

\footnotetext{
24 See Bree Hadley, Theatre, Social Media, and Meaning Making (Cham: Palgrave Macmillan, 2017), 2.

25 See Hadley, Theatre, Social Media, and Meaning Making, 2-3.

26 See Patrick Lonergan, Theatre and Social Media (London: Palgrave Macmillan, 2016), 76.

27 Hadley, Theatre, Social Media, and Meaning Making, 4.

28 See Sullivan, "Live to Your Living Room," 94.

29 See Sedgman, The Reasonable Audience, 12.
} 
live chats when watching livestreams, Kögler responded: "When I'm looking at something, I focus on it completely. The chats would just distract me." ${ }^{30}$

This changing reception is primarily connected with live-streamed performances, and the live-stream format does not dictate whether spectators appear to each other at all. ${ }^{11}$ Nevertheless, other digital theater productions have been designed for participation and immersion, addressing their audiences differently via their own hybrid basic arrangements, and involving them with stronger commitment. Thus, there definitely are digital performances that engage their audiences with attention and concentration and, through their technical and aesthetic structuring, form them into ephemeral, temporal communities. How this succeeds in digital spaces will be examined below by analyzing two productions from Germany that were produced and performed during the covid-19 pandemic.

\section{Audience as a Digital Community of Players: Homecoming by machina $\mathrm{eX}$}

machina $\mathrm{eX}$ is an independent German theater group working at the interface of computer games and theater. The collective writes about their own work: "machina eX develops immersive plays which are at the same time walk-in computer games." ${ }^{2}$ With Lockdown and Homecoming, the group realized two digital game theater productions during the pandemic, which referred to the pandemic situation in terms of content and were realized mainly via the messenger service Telegram. For the realization of Lockdown and Homecoming, machina eX programmed its own software, which was connected to Telegram. ${ }^{33}$ Homecoming, which was part of the digital program of the Berliner Theater HAU and which I played on October 15,2020 , is an example of how a small audience can be immersed in a digital performance with the help of computer game logic, and how audience members can become co-creators of a performance in digital space.

In Homecoming, two days prior to the theatrical event, the audience members were sent a letter to their home address, containing documents from a fictitious new EU authority, EurAvoid, which informed about an opportunity to take part in an online test, to find out whether they were suitable for the "Shelter" support program. This program offered support against the mental and physical health

30 Konrad Kögler, “Der Perlensucher," interview by Christian Rakow, Nachtkritik.de, May 21, 2021, https://www.nachtkritik. de/index.php?option=com_content\&view=article\&id=19553.

31 There are certain possibilities for audience members to become visible to each other in a live stream. On YouTube, for example, this can take place through the use of live chats linked to the live-stream video, or, in a more abstract manner, through a counter in the video player display, showing the current number of viewers.

32 machina eX,"About," accessed May 29, 2021, https://www.machinaex.com/en/about.

33 See Grit Krause, "Homecoming: Digitales Rätseltheater zum Mitmachen in Hellerau," Mitteldeutscher Rundfunk, November 16, 2020, https://www.mdr.de/kultur/theater/homecoming-dresden-hellerau-machina-ex-10o.html. 
consequences of the lockdown. As a participant in Homecoming, it was up to me whether I wanted to take part in this hybrid prologue before the performance. In a previous instruction e-mail for the audience, machina eX encouraged the audience members to make the test as an additional preparation for Homecoming, and they recommended installing the desktop version of Telegram for the day of the performance. On the day of my game, at the official starting time $8 \mathrm{pm}$, I was added to the Telegram chat group "Abi o1-The struggle is real" together with two other unknown players. We were welcomed by an account called Marie Giffinger.
Marie Giffinger [20:00]: Hey folks!
Marie Giffinger [20:00]: I thought, I open a group ... it's easier!
Marie Giffinger [20:00]: Besides, it is always most beautiful when we are all united! 鼣

The audience was addressed and formed in the chat group as an association of former classmates. Driven by the figure of our former classmate Marie, we, the accounts TA, Milena, and I, set out to find Rapha, another former classmate, who has shut himself off during the lockdown, and about whom Marie was worried. Besides that, we had to find out what the Shelter program was all about. We communicated exclusively via the Telegram chat group. Marie provided us with hints, sent us audio and text messages, and posted photos and videos in real time. After a while, I and the other players realized that Marie was a chatbot. Nonetheless, it was not always clear which of Marie's messages were programmed in a fixed script or if some of them were written live by a performer. A few times during the performance, audio messages also appeared in the group, where Marie's human voice spoke directly to us as players and sometimes commented on our current chat.

Homecoming is structured as a theatrical puzzle parkour, with the stations and information distributed on various websites and blogs created especially for the production. Time and again, our small group had to find information and solve riddles and puzzles that pushed the plots forward. We searched various homepages, looked through video diary entries, called telephone numbers and tried to contact Rapha, who also had a Telegram account. We compiled the results in the Telegram chat group, which served as our central place of communication. For example, we often had to put together numerical codes with which we could log on to homepages designed especially for Homecoming. To illustrate this, a documented extract from our chat group, where we were just trying to find the access data for the Shelter program, went as follows:

\footnotetext{
${ }^{34}$ Extract of the Telegram-Chatgroup Abi*01-The struggle is real, October 15, 2020, translation-KP.
} 
Marie Giffinger [ 20:37]: Have you seen these black and white squares on Muckenschmidt's desk? I’ve seen something similar somewhere before ...

TA [ 20:37]: I don't know where.

Milena [20:37]: the ID card?

TA [20:37]: I see it on the ID card

Milena [20:37]: From shelter test?

Milena [20:39]: kai where are you?

Kai Mesato [20:39]: Thinking

TA $[20: 39]^{35}$ : that is always good ... and?

All participants made use of Telegram emojis, stickers, and GIFs. In this way, TA, Milena, and I cheered Marie on with GIFs, stickers, and encouraging messages as she hurriedly made her way to Rapha's home in the final phase of Homecoming, keeping us up to date with live voice messages.

The choice of Telegram as the central software, which determines the place and structure of communication, generates its own form of digital liveness. This can result in the players' different experience of the time spent together in the game. The audience in Homecoming is a reading and writing audience, and this has consequences for the perception of temporality. Although messages are sent in real time through the messenger service, as players visit different websites, make phone calls, and watch videos to complete and advance the game, it is often the case that messages sent by other players are not necessarily seen and read immediately. Sometimes, while I searched a homepage, various unread messages accumulated in the group chat, and while I read through them, the next message arrived at the same time.

The follow-up discussion also took place in Telegram, in another group, where audience members could exchange impressions and questions with other players who had played Homecoming on the same day in their own small groups, as well as with members of machina $\mathrm{eX}$ and the performers of the main characters Marie and Rapha.

Through the collaborative design of the game, the audience had to solve the tasks as a team. In this way, the audience in Homecoming was formed as a small community of players, who only encounter each other through digital communication. This was supported within the narrative by addressing the players as a group connected through having attended the same school. However, this narrative and community also had to be filled with life, in other words: with action. We as individual players became mutually visible in the chat group through our own text messages, and we could engage in collective action and play our way through the story of Homecoming. Our communication was significantly determined by

\footnotetext{
35 Extract of the Telegram chatgroup "Abi"01-The struggle is real", ellipses original.
} 
the functionality of the application Telegram. The players interacted in a written orality that is common for everyday communication via messenger services and social networks. Thus, it is helpful to include current research on language and writing in social media, as presented by sociologist Elke Wagner in her study Intimisierte Öffentlichkeiten: Pöbeleien, Shitstorms und Emotionen auf Facebook. Wagner points out that in these contexts, language functions not only as a medium of information distribution but also as a medium of perception. In relation to relevant language and media research on social media, Wagner describes the emergence of a digital intimacy in social networks, which is connected to the use of emoticons or non-words such as written-out sounds. For example, the use of emoticons and non-words can take over the function of physical gestures in these digital interactions. In the context of social networks, they help maintain contact and create feelings of connectedness between the participants. ${ }^{36}$ In this way, Homecoming also constitutes a certain kind of encounter and community building among the audience, which is structured according to the principles of the messenger service and the logic of the game. As players, we have a responsibility to each other, because part of the charm of Homecoming is that we can sift through the material together, solve the various tasks and puzzles, and thus advance the narrative. For the shared time of the play, this can have an immersive effect: the audience "represents an active and constitutive element of the environment in which they find themselves." ${ }^{37}$ Homecoming is a hybrid event that combines theatrical storytelling with digital daily communication and the mechanisms of a point-and-click adventure game. Being the audience at Homecoming means being part of an active, focused, and collaborative digital community of players.

\section{“Turn your camera on": The Hybrid Mourning Community of Sterben by Kaufmann/Witt}

Another kind of community forming unfolded during the performative mourning ceremony Sterben, staged by the directing duo Saskia Kaufmann and Raban Witt in April 2021 at the Hamburg cultural center and theater Kampnagel. According to the directors, the idea for the production came about before the pandemic ${ }^{38}$ but

\footnotetext{
36 See ElkeWagner, Intimisierte Öffentlichkeiten: Pöbeleien, Shitstorms und Emotionen aufFacebook (Bielefeld: transcript, 2019), 75-77, http://www.transcript-verlag.de/978-3-8376-4026-7.

37 Doris Kolesch, "Immersion and Spectatorship at the Interface of Theatre, Media Tech and Daily Life: An Introduction," in Staging Spectators in Immersive Performances, eds. Doris Kolesch, Theresa Schütz, and Sophie Nikoleit (New York: Routledge, 2019), 5 .

38 See Robert Matthies, "Hurra, Wir Leben Noch," taz, die Tageszeitung, April 17, 2021, https://taz.de/Trauerfeier-fuer-Lebende-in-Hamburg/!5763026/.
} 


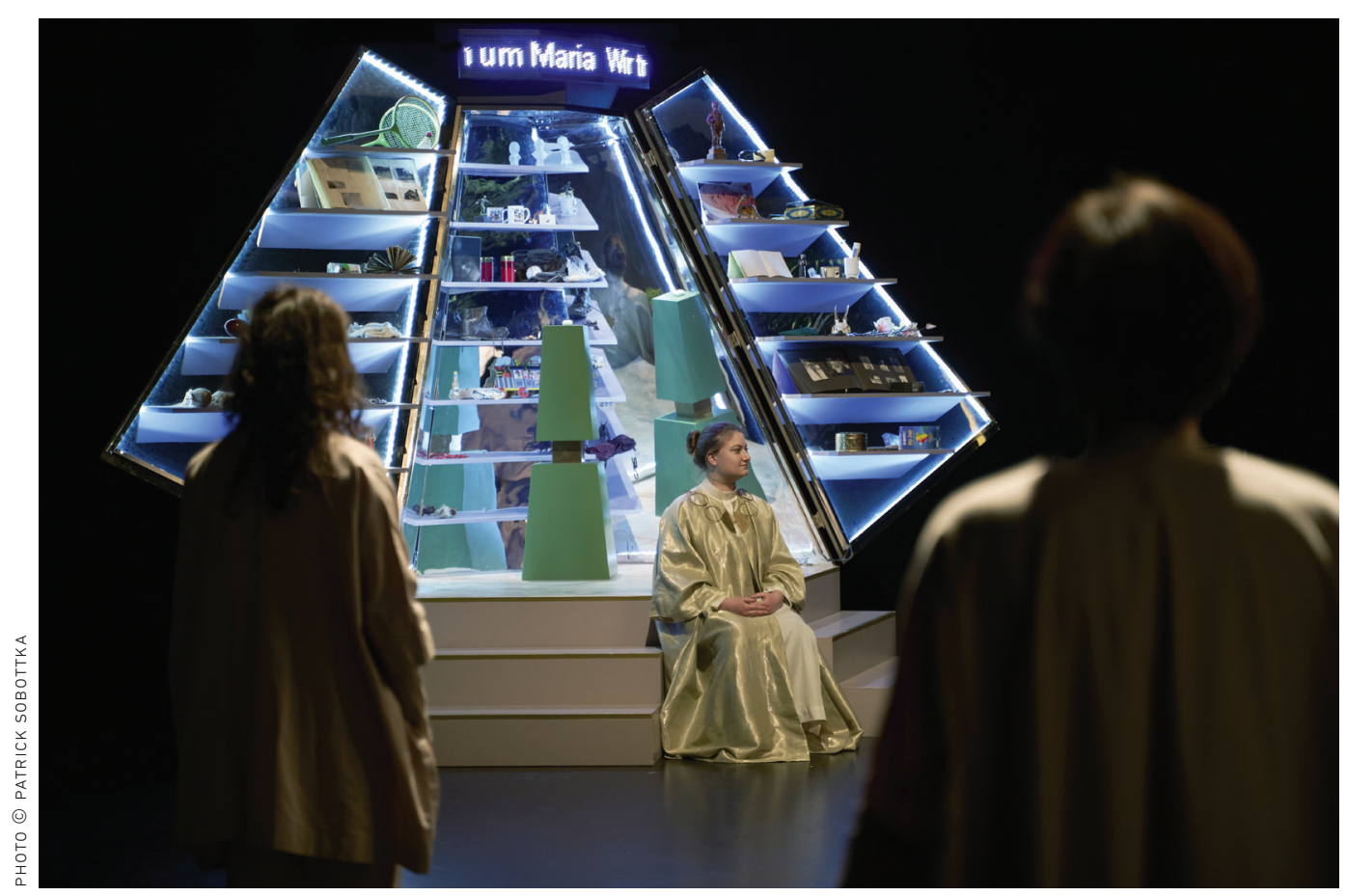

Sterben by Saskia Kaufmann and Raban Witt, 2021

the confrontation with one's own mortality against the background of daily announcements of death figures took on special relevance in the context of COVID-19. Sterben shows how despite different perceptual conditions, the performers and the audience can also form a medialized, hybrid, temporary community.

Sterben is conceived as a funeral service, where the future death of a person is mourned while the person is still alive. From the audience's perspective, there are two ways to participate. One can either go through the ceremony as the person to be mourned by the ensemble-in bodily co-presence on site at Kampnagel, being at the center of the funeral service-or participate as a guest at the funeral service of another person. The latter option, because of the COVID-19 pandemic and the ensuing lockdown in April 2021, was organized through the Zoom video conferencing software. I attended the funeral service for Aglaja Bitzinger on April 22, 2021 via Zoom.

In advance, the guests of the funeral service received an email with instructions. They were told to have a pen and notepad ready, as well as a drink to toast with. They were also advised that the cameras on their devices should be turned on throughout the service, as this was a necessary component of the performance. 
After the start of the Zoom meeting, the audience was greeted by a performer, who carried out a technical and thematic introduction. Technically, setting the correct arrangement of the view in Zoom was of major importance. The course of the event was explained, and the thirty guests were prepared for several sections of the funeral service, and told where and when they should get involved. The audience rehearsed some of these moments together with the performer. After the preparation, the performer took the audience backstage to the performance via her end device. Various performers introduced themselves briefly as they passed by, waving at the camera, and the audience got a look behind the scenes, where the performers made final preparations before the ceremony. Then the mourning ceremony began: seven performers of different ages and genders moved to the location of the ritual in white, flowing robes. At the side of the room where the choreographic and ritual part of the mourning ceremony took place, Aglaja, who was to be mourned, also dressed in a white robe, sat waiting at the steps of a kind of altar. In front of her were white benches arranged in an octagon, behind them palm trees as well as wooden boards suspended in a semicircle, which defined the space and served as projection screens. The audience were presented with this space on their screens via different, changing camera settings. A cameraman, also dressed in white, moved around the performers and filmed the one-hour ritual.

If one followed the Zoom settings from the introduction, the other members of the audience were not visible. Sterben, however, did not forget about the audience, and brought them into the space of the performance, as well as into the image of the live video, through the use of video projection. The videos of each audience member were projected onto the semicircle of hanging screens. The continuous recordings of the faces and partly bodies of all audience members watching the mourning ritual were thus always present for Aglaja and the performers in the space. Sometimes, the cameras at Kampnagel also filmed these projections, reminding audience members as individuals that they were not alone watching the performance. When I saw my own video image in the room, I was again made aware of my visibility to the others. The projection walls, where the audience videos were lined up and arranged next to each other, were hanging at about the head height of the performers, suggesting a semi-circular grandstand from which the audience looks down on the ceremony. This arrangement was present on site, but it did not have much to do with the camera-guided perspective of the audience.

The audience members saw the images of the cameraman and other cameras alternately on their screens at home. In this part of the performance, they got to see a wide live-edited repertoire of cinematic shots from extreme close-ups to fast and slow tracking shots and camera pans. While at the beginning of the welcome section, the feeling of accompanying the performers privately through the camera of mobile devices was still present, later a different visual experience emerged, reminiscent of a film or a television show through its securely directed images. Thus, when a performer began a eulogy addressed directly to Aglaja, the 


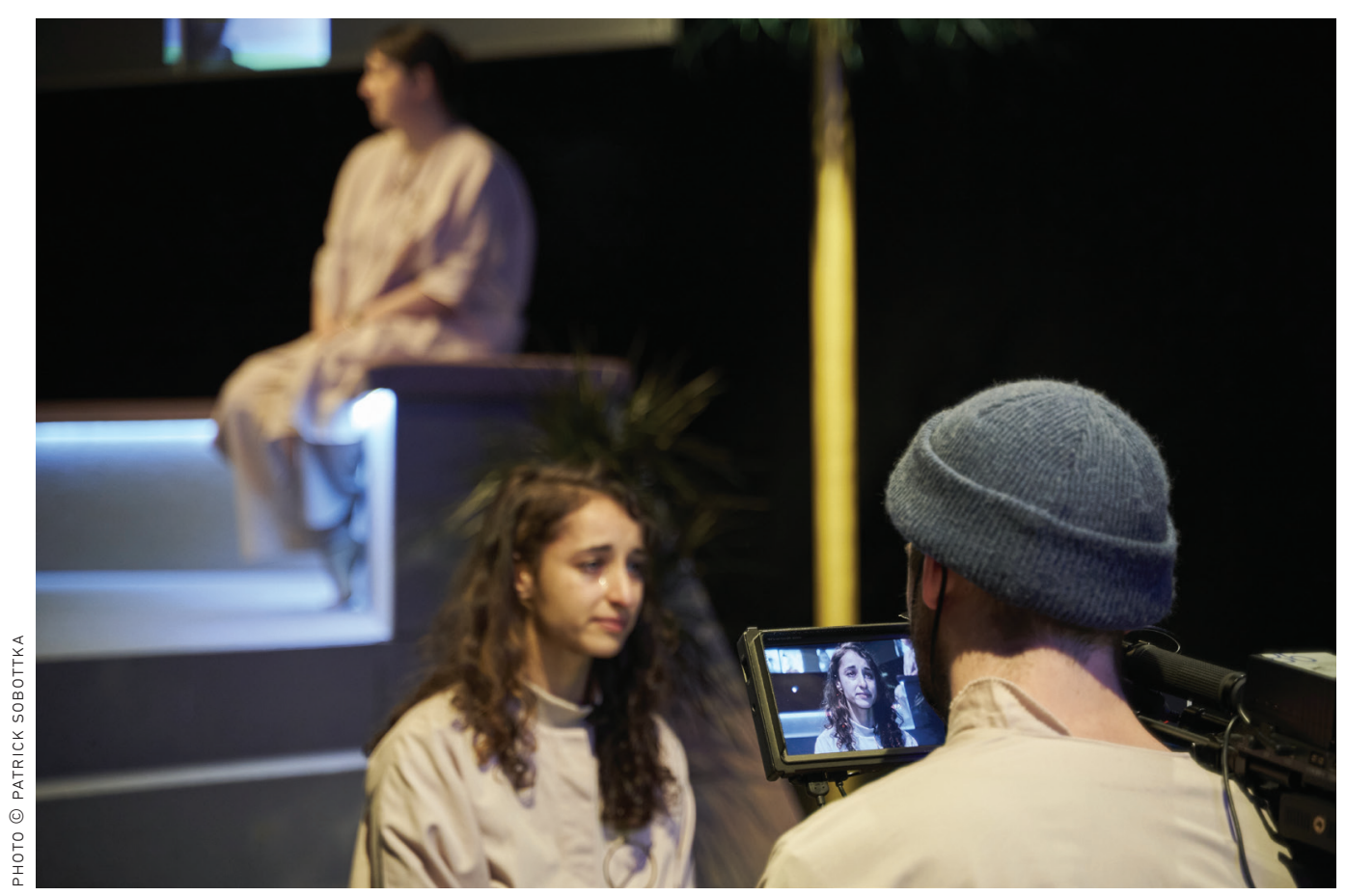

Sterben by Saskia Kaufmann and Raban Witt, 2021

camera perspective constantly switched between the speaker and a close-up of Aglaja's face as she listened intently.

After the eulogy, another performer kneeled down in front of her and cried. The performers moved choreographically and spoke in turn and in chorus about dying. They called out things that Aglaja will no longer do after her death. The design and process of the ceremony recalled various religious and spiritual symbols and practices, but they were not tied to any particular religion. During the course of the ceremony, the audience heard many personal details from the life of Aglaja. Her close friend was also present in the digital audience, and was greeted and addressed by the performers several times.

The audience members were also invited to actively participate in the mourning ritual. They were asked to formulate a message about life and death, put it on paper with the pens they had brought, and show it through their camera. At a later point, the audience members could address Aglaja directly. The majority used this possibility. Many said that they were grateful for such a personal insight into Aglaja's life, and expressed a strong attachment, even though-with the exception of the 
friend-they did not personally know the person being mourned. Afterwards, the mute was lifted on everyone's videos and the "chaos concert" started, which had been rehearsed at the beginning. The audience members made sounds with a wide variety of instruments and objects, thus jointly creating a roaring soundscape, which could also be heard on site at Kampnagel. Towards the end of the funeral service, Aglaja was left alone by the performers as well as the audience for five minutes of solitude. During this time, the audience was divided into groups of two via Zoom's break-out session function to talk about death, loss and mortality. When everyone returned to the main session, Aglaja was there again, the camera perspective switched back to a mobile device, and audience members raised their glasses with Aglaja and a performer at the end. Sterben then transitioned into a relaxed conversation and exchange about the project, with the audience gradually leaving the Zoom meeting, one by one.

During the performance, the community between the audience, the person mourned, and the performers was shaped by different functions and medialized positions in the ritual. However, this does not detract from the emotional connection that was established between myself and others. In particular, one's own visibility through the imperative of the switched-on camera and the possibility of addressing personal words to the mourned one develops a communal intimacy and also a commitment and authority that is unusual for digital spaces and difficult to escape.

The reception and the kind of community created during Sterben is characterized by hybridity. On the one hand, audience members get the feeling of watching a television show through the camera-mediated guidance of our gaze; on the other hand, they are witnessing part of the scenery through their own visibility, of which they are also constantly reminded by the camera movement. Through active involvement, the audience also becomes a performative part of the ritual. The audience is more than just visible and partially audible during Sterben. Within the framework of medial possibilities, the audience also contributes its performative role to the production of the performance.

\section{Digital Communities and Their Potentials: What Does It Mean to Be an Audience in Digital Times?}

In a digital space, audience members must first find and perceive one another. The choice of platform and the format of the production determines the mode of mutual perception and communication. If digital theater productions want to enable their spectators to become an audience, their choice of platform and programs for each performance matters significantly, as they influence and structure encounters between members of the audience, as well as between the audience and performers. In order to gather as an audience in digital spaces, individual 


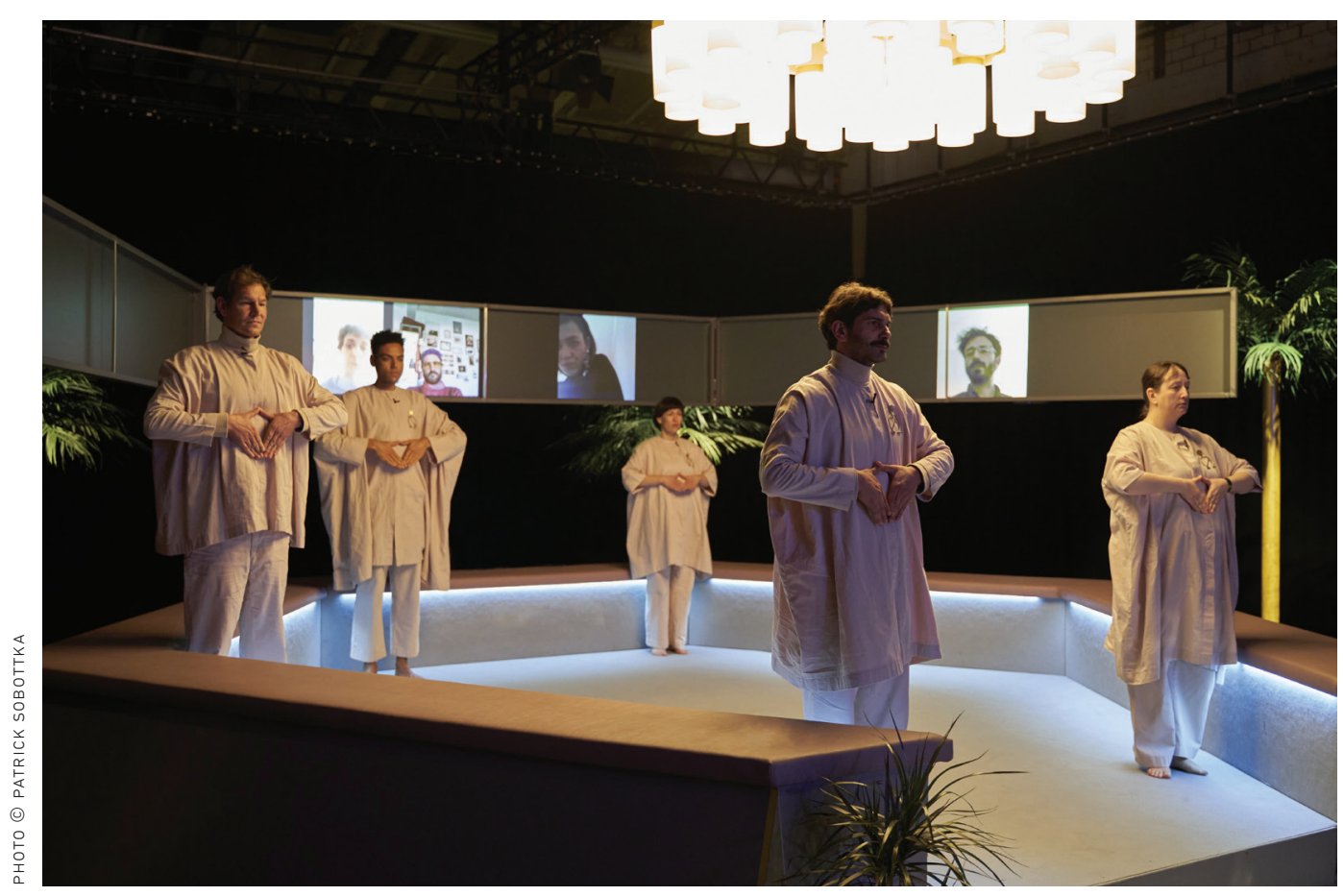

Sterben by Saskia Kaufmann and Raban Witt, 2021

spectators must be able to experience the presence of others. This is achieved in different ways in the two productions discussed above. While in Homecoming we shared responsibility for the progress of the game and became visible to each other through active communication, in Sterben the imperative of the camera being switched on united us in a common ritual.

Homecoming and Sterben were staged on platforms that potentially many of us are familiar with through our everyday digital work and communication. The spaces of expectation and experience of theater, digital everyday practices, as well as special forms of assembly addressed in the productions, such as funeral ceremonies or games, are mixed here, showing the hybridity of digital theater forms. These hybrids raise new questions relevant for audiences in digital performances. How do I organize my own reception situation at home? Which device do I use? Do I participate in a digital performance at home alone or together with friends, or do they join in live from their own private spaces? Do I turn on my camera? Do I chat and comment under a pseudonym or use my real name? How do I perform as an audience member online? 
In digital performances, the audience sometimes acts not only as a gathering of listeners and spectators, but it can also become a gathering of readers and writers. They send emoticons or design their own visibility if the cameras on their devices are switched on. However, for audience members to appear in digital performances with their own performative acts, whether in writing or in front of a camera, there needs to be a promise that the theatrical event is, at least in part, designed as a reciprocal social situation. Depending on the possibilities offered by the corresponding software, members of an audience can also stage and perform themselves. The hybridization of theatrical events in the context of digitality thus also entails new repertoires of action for audiences. Although these are strongly predetermined by the structure of the particular platform, they are at the same time fluid, as different expectations and conventions of theater and digital communication culture meet and get entangled here.

Even if certain forms of digital theater foreground a stronger emphasis on the individual position of reception and spectatorship, the two examples discussed show that digital audiences can also produce temporal communities with their own qualities and structures. In both performances, there is a fleeting, temporary experience of a communality that goes beyond a shared reception situation. In Sterben the audience becomes a virtually present part of a community of mourners, whereas in Homecoming its members have to form themselves into a community of action, where individuals take on responsibility for each other and for the successful completion of the game. These temporary communities were primarily designed for small audiences. Whether and how forms of community can also be created for larger audiences of digital theater productions remains to be seen.

Digital performances allow a new sensual access to the experience of a mediamediated community. Theater, in particular, can try to explore the limits of a mediated immediacy of theatrical encounters. In addition to Patrick Lonergan's observation that "social media sites ... become ... a way for audience members to see themselves within a performance," 39 it can be stated that in many apps there are new possibilities of self-reflexivity for the audience-whether it is that one's own messages materialize to oneself and can be reread, as in Homecoming, or that in Zoom it is possible to observe not only the performers but also one's own image and performance in the camera.

Looking ahead, the question arises as to the emancipatory character of these new forms of communities in digital theater. This political question may seem surprising, since in Sterben and Homecoming digital communities were politically undefined. Nevertheless, digital performances often open up new forms of accessibility for many people and can thus have a democratizing effect on cultural participation in particular societies. In digital performances, people who previously

39 Lonergan, Theatre and Social Media, 72. 
would not have been able to do so due to physical distance are empowered to form an audience, and possibly a community. In Sterben, I became part of a digital mourning community with over thirty other people from all over Germany, virtually united through the digital communication practices at Kampnagel in Hamburg. Also, in Homecoming, the members of my group were in a range of cities throughout Germany. In the constitution of audiences in digital performances lies the potential to create temporary communities that are no longer bound to spatial borders and perhaps national borders. Digital performances have the potential to create new-sometimes transnational-communities of audiences and thus create new places for encounter and discourse. Against this hopeful statement, it must of course be said that many parts of the world do not always have access to internet without censorship, and that the availability of digital infrastructure and the personal data volume, even in an industrialized country like Germany, sometimes still widely varies. Finally, of course, a common language must also be agreed upon in digital spaces, and here the conditions of access are just as varied.

Even though, as in many discourses on digitalization, greater accessibility is linked to the promise of democratization, digital performances do not democratize the theatrical event itself. Rather, against the backdrop of the increasing commodification of digital spaces, theater makers must critically engage with the algorithms and functional logics that are the basis for the formation of communities in digital spaces. It is precisely the promise of equality within community in the digital sphere that must be questioned here, especially from the perspective of the audience. In many platforms, there is a large imbalance of power between users and providers, and even when we meet digitally in the theater as a community, the question still remains: Who has administrator rights?

Nonetheless, the political potential of increased accessibility and the associated mobility of aesthetic experiences in an increasingly networked world should not be underestimated. Theater as an art form has the potential to experiment with communality in digital space and to explore and recreate it. Whether this will have emancipatory effects will depend above all on how and with what aims artists and theaters will design digital spaces as places of assembly for their audiences, and what forms of temporal communities can evolve there.

\section{Bibliography}

Bennett, Susan. Theatre Audiences: A Theory of Production and Reception. London: Routledge, 1994.

Brandl-Risi, Bettina. "Genuss Und Kritik: Partizipieren Im Theaterpublikum.” In Vom Publicum: Das Öffentliche in Der Kunst, edited by Dietmar Kammerer, 73-90. Bielefeld: transcript Verlag, 2014. 
Fischer-Lichte, Erika. "Aufführung." In Fischer-Lichte et al., Metzler Lexikon Theatertheorie, 15-26.

Fischer-Lichte, Erika, Doris Kolesch, and Matthias Warstat, eds. Metzler Lexikon Theatertheorie. Stuttgart: Verlag J.B. Metzler, 2014. http://dx.doi.org/10.1007/978-3-476-05357-2.

Freshwater, Helen. Theatre \& Audience. London: Palgrave Macmillan, 2009.

Glogner-Pilz, Patrick, and Patrick S. Föhl, eds. Handbuch Kulturpublikum: Forschungsfragen und-befunde. Wiesbaden: Springer vs, 2016.

Hadley, Bree. Theatre, Social Media, and Meaning Making. Cham: Palgrave Macmillan, 2017. Heim, Caroline. Audience as Performer: The Changing Role of Theatre Audiences in the Twenty-First Century. New York: Routledge, 2015.

Hermann, Max. "Das theatralische Raumerlebnis." In Zeitschrift für Ästhetik und allgemeine Kunstwissenschaft: 4.Kongress-Bericht 25 (1931): 152-163.

Kolesch, Doris. "Immersion and Spectatorship at the Interface of Theatre, Media Tech and Daily Life: An Introduction." In Staging Spectators in Immersive Performances, edited by Doris Kolesch, Theresa Schütz, and Sophie Nikoleit, 1-17. New York: Routledge, 2019.

Kolesch, Doris, and Hubert Knoblauch. "Audience Emotions." In Affective Societies: Key Concepts, edited by Jan Slaby and Christian von Scheve, 252-263. London: Routledge, 2019. Lonergan, Patrick. Theatre and Social Media. London: Palgrave Macmillan, 2016.

Roselt, Jens. "Gemeinschaft/Kollektivität." In Fischer-Lichte et al., Metzler Lexikon Theatertheorie, $128-131$.

Sauter, Wilmar. "Publikum." In Fischer-Lichte et al., Metzler Lexikon Theatertheorie, 273-279. Sedgman, Kirsty. The Reasonable Audience: Theatre Etiquette, Behaviour Policing, and the Live Performance Experience. Cham: Springer International Publishing, 2018. https:// doi.org/10.1007/978-3-319-99166-5.

Sullivan, Erin. "Live to Your Living Room: Streamed Theatre, Audience Experience, and the Globe's A Midsummer Night's Dream." Participations: Journal of Audience \& Receptions Studies, 17, no. 1 (2020): 92-119.

Turner, Victor. "Liminalität und Communitas." In Ritualtheorien: Ein einführendes Handbuch, edited by Andréa Belliger and David J. Krieger, 251-261. Wiesbaden: vs Verlag für Sozialwissenschaften, 1998.

Wagner, Elke. Intimisierte Öffentlichkeiten: Pöbeleien, Shitstorms und Emotionen auf Facebook. Bielefeld: transcript, 2019. http://www.transcript-verlag.de/978-3-8376-4026-7. Warstat, Matthias. “Liminalität.” In Fischer-Lichte et al., Metzler Lexikon Theatertheorie, 197-199.

\section{Abstract}

\section{New Forms of Communities? The Constitution and Performance of Audiences in Digital Theater during the COVID-19 Pandemic}

The COVID-19 pandemic plunged many theaters around the world into a temporary crisis and favored the rise of digital theater forms. This article investigates how the reception of theater changes in the digital space and, above all, how audiences as a social dimension of 
theatrical performances must first be constituted separately there. Based on performance analysis of the digital theater productions Homecoming and Sterben from Germany, the significance of the digital infrastructure for the assembly, performance, and action repertoires of these theater audiences is discussed. The author examines how audiences can be formed into different temporal communities in the digital space. These temporal communities are characterized by hybridity and have the potential to enable intense theatrical encounters across spatial boundaries.

\section{Keywords}

audience, pandemic, German theater, community, reception, performing arts, digitality, hybridization

\section{Abstrakt \\ Nowe formy wspólnotowości? Tworzenie się i performanse publiczności teatru cyfrowego podczas pandemii COVID-19}

Pandemia covid-19 pogrążyła wiele teatrów na świecie w okresowym kryzysie, równocześnie sprzyjając rozwojowi cyfrowych form teatralnych. Przedmiotem artykułu są zmiany w odbiorze teatru w przestrzeni cyfrowej, a przede wszystkim konieczność odrębnego ukonstytuowania się tam publiczności, rozumianej jako społeczny aspekt przedstawień teatralnych. Analiza performatywna dwóch cyfrowych produkcji teatralnych z Niemiec, Homecoming i Sterben, jest podstawą refleksji nad znaczeniem infrastruktury cyfrowej dla możliwych form gromadzenia się, doświadczeń i działań tego rodzaju publiczności teatralnej. Autor bada, jak publiczność może tworzyć różne tymczasowe wspólnoty w przestrzeni cyfrowej. Wspólnoty te odznaczają się hybrydycznością i umożliwiają intensywne spotkania teatralne pomimo fizycznego dystansu.

\section{Słowa kluczowe}

publiczność, pandemia, teatr niemiecki, wspólnota, odbiór, sztuki performatywne, cyfrowość, hybrydyzacja

\section{KAI PADBERG}

member of the Friedrich Schlegel graduate school of literary studies at Freie Universität Berlin. He studied theatre, media, and sociology at Friedrich-Alexander University Erlangen-Nuremberg and at the Freie Universität Berlin. Since October 2019, he has been working in the research project "Extended Audiences: Audience Performances and Public in Transition" in the Cluster of Excellence Temporal Communities at Freie Universität Berlin. 